Dymock, I. W. (1966). British fournal of Cancer, 20, 236.

Edwards, D. N. (1968). In Annual Survey of the Liverpool Regional Radiotherapy Service, p. 20. Clatterbridge Hospital West, Wirral.

therapy Service, P. 20. Clatterbridge Hosp

Martin, C. L., and Rogers, F. T. (1924). American fournal of Roentgenology, $11,280$.

Mason, G. R., Dietrich, P., Friedland, G. W., and Hanks, G. E. (1970). Clinical Radiology, 21, 232.

Moss, W. T. (1957). American fournal of Roentgenology, 78, 850
Ratzkowski, E., and Hochman, A. (1968). Acta Radiologica. Therapy, Physics, Biology, 7, 417

Salvesan, H. A., and Kobro, M. (1939). Acta Medica Scandinavica, 102, 277. Sauer, W. G. (1959). Postgraduate Medicine, 26, 352.

Scudamore, H. H., and Green, P. A. (1959). Postgraduate Medicine, 26, 340

Scudamore, H. H., and Green, P. A. (1959). Postgraduate Medicine, 26, 340.

Steckel, R. J., Ross, G., and Grollman, J. H. (1968). Radiology,

Tankel, H. I., Clark, D. H., and Lee, F. D. (1965). Gut, 6, 560 . ood, I. J., Ralston, M., and Kurrle, G. R. (1963). Australasian Annals of Medicine, 12, 143.

\title{
Recurrent Hyperkalaemia due to Selective Aldosterone Deficiency: Correction by Angiotensin Infusion
}

\author{
J. J. BROWN, R. H. CHINN, R. FRASER, A. F. LEVER, J. J. MORTON, J. I. S. ROBERTSON, \\ M. TREE, M. A. WAITE, D. M. PARK
}

British Medical fournal, 1973, 1, 650-654

\section{Summary}

A patient with recurrent weakness and blurring of consciousness associated with hyperkalaemia due to aldosterone deficiency is reported. The plasma concentrations of renin, angiotensin $\mathrm{II}$, and aldosterone were low and did not increase during sodium deprivation. Blood angiotensin I was also low while renin-substrate concentration was normal. Infusion of angiotensin produced a distinct rise in plasma aldosterone. The patient was treated successfully with fludrocortisol.

The results support the concept that the reninangiotensin system is an important regulator of aldosterone secretion and that in the syndrome of acquired selective hypoaldosteronism the primary abnormality may be a deficiency of renin. It is suggested that a selective lack of aldosterone should be considered in all cases of otherwise unexplained hyperkalaemia.

\section{Introduction}

The association of acquired aldosterone deficiency with normal cortisol levels was first reported by Hudson et al. (1957). The syndrome seems to be rare since only 21 further cases have been recorded (Skanse and Hokfelt, 1958; Hill et al., 1959; Lambrew et al., 1961; Rick et al., 1962; Posner and Jacobs, 1964; Wilson and Goetz, 1964; Gerstein et al., 1968; Vagnucci, 1969; McGiff et al., 1970; Vagnucci, 1970; Ferrara et al., 1970; Perez et al., 1972; Schambelan et al., 1972; Mellinger et al., 1972; Weidman et al., 1972; Brown et al., 1972a).

In some instances the deficiency of aldosterone was attributed, at least in part, to a biosynthetic block (Vagnucci, 1969; Jacobs and Posner, 1964; Perez et al., 1971); in most of the others the pathogenesis remained completely obscure.

The objectives of the present paper are two-fold; firstly, to report another case of this rare but easily treatable condition, and, secondly, to provide evidence supporting the concept first

M.R.C. Blood Pressure Unit, Western Infirmary, Glasgow G11 6NT J. J. BROWN, F.R.C.P., Consultant Physician

R. H. CHINN, M.R.C.P., Medical Registrar

R. FRASER, PH.D., Member of Scientific Staff

A. F. LEVER, F.R.C.P., Director and Consultant Physician

A. F. MORTON, PH.D., Member of Scientific Staft

J. J. MORTON, PH.D., Member of Scientific Staff
J. I. S. ROBERTSON, F.R.c.P., Consultant Physician

M. TREE, PH.D., Technical Officer

M. A. WAITE, M.R.C.P., Senior Medical Registrar

University Department of Neurology, Institute of Neurological Sciences, Southern General Hospital, Glasgow G51 4TF

D. M. PARK, M.R.C.P., Research Fellow (Present appointment Lecturer in Medicine, University of Southampton) mentioned by Jacobs and Posner (1964) and subsequently by others (Wilson and Goetz, 1964; Gerstein et al., 1968; Vagnucci, 1969; McGiff et al., 1970; Ferrara et al., 1970; Perez et al., 1972; Schambelan et al., 1972; Weidman et al., 1972) that the aldosterone deficiency is secondary to suppression of the reninangiotensin system.

Some of our observations in this patient have been reported in brief elsewhere (Brown et al., 1972a; 1972b). We present here a fuller account including the necropsy and histological findings.

\section{Methods}

Most of the laboratory methods used were those listed in a recent publication (Brown et al., 1972c). The additional techniques used were: blood angiotensin I concentration, Waite (1972, 1973) (normal range 11-88, mean $51 \mathrm{pg} / \mathrm{ml}$ ); plasma reninsubstrate, Tree (1973) (normal female range 0.45-1.28, mean $0.85 \mu \mathrm{mol}$ ); plasma "cortisol" by a competitive protein binding technique of Murphy (1967) (normal range at 09.00 hours: 6-18, mean $11.8 \mu \mathrm{g} / 100 \mathrm{ml}$ ); urine free cortisol, Beardwell et al. (1968) (normal range up to 110 , mean $42 \mu \mathrm{g} /$ day); and kidney renin extraction, Tree (1972).

The special clinical techniques used were: angiotensin infusion, Chinn and Dusterdieck (1971), using synthetic asn ${ }^{1}$ $\mathrm{val}^{5}$ angiotensin II, Hypertensin-Ciba; tests of autonomic function, Johnson et al. (1971); tests of ability to decrease or increase urine $\mathrm{pH}$ with $\mathrm{NH}_{4} \mathrm{Cl}$ (Wrong and Davies, 1959) and acetazoleamide (Counihan et al., 1954) respectively.

\section{Case History}

The patient, a woman of 81 , had remained in good health until early 1971 when she was referred to hospital elsewhere complaining of unusual tiredness, generalized weakness, loss of weight, constipation, and pain with stiffness particularly affecting the wrists and the hand joints. Apart from some swelling around the interphalangeal joints, there were no abnormal features on examination (blood pressure $164 / 76 \mathrm{~mm} \mathrm{Hg}$ ). Investigation showed a normal blood count (Hb $13.2 \mathrm{~g} / 100 \mathrm{ml}$, W.B.C. $7,300 / \mathrm{mm}^{3}$, E.S.R. $12 \mathrm{~mm}$ in one hour) and a midstream urine without protein, reducing substance, or growth on culture. A chest $x$-ray film, intravenous urography, barium meal and barium enema examination showed nothing abnormal. The serum potassium concentration was initially normal $(4.0 \mathrm{mEq} / \mathrm{l}$.) but during the next few weeks the level increased to $7.0 \mathrm{mEq} / 1$. accompanied by a small fall in serum $\mathrm{Na}$ to $138 \mathrm{mEq} / \mathrm{l}$. and an appreciable rise in blood urea $(80-122 \mathrm{mg} / 100 \mathrm{ml})$. At that stage oral treatment with a cation exchange resin-sodium polystyrene sulphonate (Resonium-A) $45 \mathrm{~g} /$ day - and sodium bicarbonate $(20 \mathrm{~g} /$ day) resulted in a prompt return of the serum electrolytes and blood urea to more normal levels.

The fatient was then discharged from hospital and remained 
TABLE I-Tests of Adrenocortical Function (Figures in Parentheses are Normal Ranges)

\begin{tabular}{|c|c|c|c|c|c|c|c|c|c|}
\hline \multirow{3}{*}{ Time in Hours } & \multicolumn{6}{|c|}{ Plasma } & \multicolumn{3}{|c|}{ Urine } \\
\hline & \multicolumn{2}{|c|}{$\begin{array}{c}11-\mathrm{OHCS} \\
(\mu \mathrm{g} / 100 \mathrm{ml})\end{array}$} & \multirow{2}{*}{$\begin{array}{c}\text { Cortisol } \\
(\mu \mathrm{g} / 100 \mathrm{ml}) \\
(3-20)\end{array}$} & \multirow{2}{*}{$\begin{array}{c}\text { Corticosterone } \\
(\mu \mathrm{g} / 100 \mathrm{ml}) \\
(0 \cdot 1-2 \cdot 3)\end{array}$} & \multirow{2}{*}{$\begin{array}{c}\text { Deoxycorticosterone } \\
\text { (ng/100 ml) } \\
(4-14)\end{array}$} & \multirow{2}{*}{$\begin{array}{l}\text { Aldosterone } \\
\text { (ng/100 ml) } \\
\text { (up to 18) }\end{array}$} & \multirow{2}{*}{$\begin{array}{l}\text { Free Cortisol } \\
(\mu \mathrm{g} / 24 \mathrm{hr}) \\
\text { (up to 110) }\end{array}$} & \multicolumn{2}{|c|}{$\begin{array}{c}\text { 17-OGS 17-OS } \\
(\mathrm{mg} / 24 \mathrm{hr})\end{array}$} \\
\hline & $\begin{array}{l}\text { Fluorimetry } \\
(6-22)\end{array}$ & $\begin{array}{l}\text { C.P.B. } \\
\text { (6-16) }\end{array}$ & & & & & & $(5-15)$ & $(3-15)$ \\
\hline $\begin{array}{l}22 \cdot 00 \\
09 \cdot 00 \\
09 \cdot 35(30 \mathrm{~min} \text { after } \\
\text { after ACTH }) \\
09 \cdot 00\end{array}$ & $\begin{array}{r}6 \\
11 \\
21\end{array}$ & $\begin{array}{c}4.8 \\
10 \cdot 5 \\
15\end{array}$ & $6 \cdot 6,10 \cdot 2$ & $0.09,0.11$ & $15 \cdot 2$ & $\underset{\text { (5 estimations) }}{\text { N.D. }}$ & $39,34,47$ & $9,9,7$ & $8,7,9$ \\
\hline
\end{tabular}

N.D. $=$ None detected. ACTH $=250 \mu \mathrm{g}$ tetracosactrin given intramuscularly. C.P.B. $=$ Competitive protein binding technique.

apparently well for about three weeks, when she again complained of weakness, particularly affecting the legs, and was noticed to be less alert. On readmission she was semiconscious but no localizing neurological signs were found. Investigation showed a recurrence of the electrolyte derangements (serum $\mathrm{K}$ more than $8.0 ; \mathrm{Na} 134, \mathrm{Cl}$ $122, \mathrm{HCO}_{3} 15 \mathrm{mEq} / 1$; blood urea $112 \mathrm{mg} / 100 \mathrm{ml}$ ), and treatment with sodium polystyrene sulphonate again led to a quick improvement both in the biochemical and the clinical abnormalities. The syndrome of weakness, staggering, decreasing alertness with pronounced hyperkalaemia, all successfully treated with a cation exchange resin, recurred on two further occasions over the next five weeks.

At that stage, August 1971, the patient was transferred to our care and was noted to be rather thin $(51.7 \mathrm{~kg})$, slightly deaf, but very alert. There was no abnormal pigmentation in the skin or buccal mucous membrane, and body hair distribution was normal; blood pressure was $180 / 94 \mathrm{~mm} \mathrm{Hg}$. There was evidence of an incomplete left homonymous visual field defect but no other abnormalities were found in either the central or peripheral nervous system.

\section{GENERAL INVESTIGATIONS}

Hb $83 \%$, W.B.C. $6,000 / \mathrm{mm}^{3}$; blood urea $46 \mathrm{mg} / 100 \mathrm{ml}$; serum creatinine $1.4 \mathrm{mg} / 100 \mathrm{ml}$; creatinine clearance $46 \mathrm{ml} / \mathrm{min} /$ $1.73 \mathrm{~m}^{2}$; serum albumin 3.6 , globulin $2.3 \mathrm{~g} / 100 \mathrm{ml}$; electrophoresis, normal; E.C.G., normal; rheumatoid factor (latex), positive; antinuclear factor, weakly positive (1/16); immunofluorescence test for antibodies to adrenal cortex, negative; total exchangeable sodium, normal $(2,661 \mathrm{mEq})$; total body water, normal $(37 \cdot 11$.). Arterial blood $\mathrm{pH} 7.40 ; \mathrm{PCO}_{2} 24$ and $\mathrm{Po}_{2} 84 \mathrm{~mm} \mathrm{Hg}$; standard bicarbonate 18; base excess, minus $8 \mathrm{mEq} / 1$. (serum K $6.5 \mathrm{mEq} / 1$.).

\section{TESTS OF RENAL TUBULAR FUNCTION}

Midstream urine: no protein; no reducing substances; no growth on culture; amino-acid chromatogram, normal; maximum urinary osmolality after vasopressin injection 5 units intramuscularly $780 \mathrm{mOsm} / \mathrm{kg} \mathrm{H}_{2} \mathrm{O}$; urinary acidification test, normal (initial $\mathrm{pH} \mathrm{6.0}$ falling to $5 \cdot 2)$; response to acetazoleamide $(500 \mathrm{mg}$, normal; urinary $\mathrm{pH}$ change from $4 \cdot 9-7 \cdot 3$ ).

\section{TESTS OF AUTONOMIC FUNCTION}

The intra-arterial pressure while supine varied from 200/76 to $210 / 80 \mathrm{~mm} \mathrm{Hg}$ with a heart rate $70-72 / \mathrm{min}$. When tipped into the head-up position the blood pressure remained practically unchanged (minimum reading $186 / 88 \mathrm{~mm} \mathrm{Hg}$ ) while the heart rate increased to a maximum of 96 beats $/ \mathrm{min}$. Sudden noise did not produce a pressor response but there was a normal response to mental arithmetic and Valsalva's manoeuvre. Radiant heating of the trunk produced vasodilatation (assessed by Hatfield flow discs) in the hand which was abolished by immersion of the other hand in cold water. Body warming produced normal sweating and ionotophoresis of acetylcholine caused normal axon reflex sweating. Urinary excretion of normetadrenaline was normal $(0.4 \mathrm{mg}$ in $24 \mathrm{hr})$.

These tests indicated normal function of the autonomic nervous system.

\section{TESTS OF ADRENOCORTICAL FUNCTION}

As shown in table I, tests of adrenocortical function showed nothing abnormal except that aldosterone was not detected in five separate plasma samples.
CHANGES IN SERUM ELECTROLYTES AND IN THE RENIN-ANGIOTENSINALDOSTERONE SYSTEM

Normal Ward Diet.-During the first two weeks, while the patient ate a normal ward diet, there was a progressive rise in the serum $\mathrm{K}+$ (from 4.8 to $6.2 \mathrm{mEq} / \mathrm{l}$.) and urea (from 42 to $68 \mathrm{mg} / 100 \mathrm{ml}$ ) accompanied by a fall in serum $\mathrm{Na}$ (141 to $133 \mathrm{mEq} / \mathrm{l}$.) and $\mathrm{HCO}_{3}(24$ to $15 \mathrm{mmol} / \mathrm{l}$.). The plasma concentrations of renin and angiotensin II were low while plasma aldosterone was undetectable (less than $2 \mathrm{ng} / 100 \mathrm{ml}$ ). In the last three days of this period she became progressively less alert and then mentally confused. Treatment with sodium polystyrene sulphonate promptly corrected the clinical and serum electrolyte abnormalities.

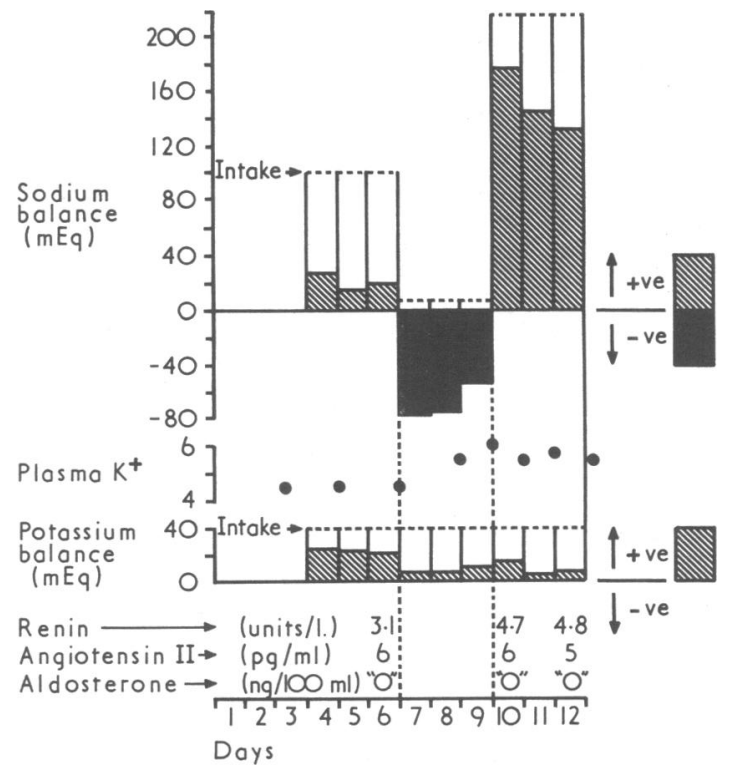

FIG. 1-Effect of sodium deprivation and loading on the excretion of $\mathrm{Na}^{+}$and $\mathrm{K}^{+}$and on the plasma concentration of $\mathrm{K}^{ \pm}$, renin, angiotensin II, and aldosterone. (The values on day 10 were obtained before starting the high sodium diet).

Effect of Sodium Deprivation and Loading.-When the sodium intake was reduced from 106 to $8 \mathrm{mEq} /$ day, the loss of sodium in the urine was excessive (cumulative loss in excess of total intake in three days was $210 \mathrm{mEq}$ ). In spite of this appreciable loss of $\mathrm{Na}$, the circulating levels of renin, angiotensin II, and aldosterone did not increase (fig. 1). After three days the low sodium diet was stopped owing to the steep increase in serum $\mathrm{K}$ to $6.0 \mathrm{mEq} / \mathrm{l}$.; the rise was halted when the sodium intake was increased to $218 \mathrm{mEq}$ /day (fig. 1).

Change of Posture.-During passive change of posture from the supine to the head-up position on a tilt table, plasma renin concentration did not change (5.1 and 5.5 units/1. supine; 4.9 units/1. erect after third tip).

Concurrent Measurements of the Circulating Concentrations of Renin, Renin-substrate, Angiotensin I, and Angiotension II.-The several components of the renin-angiotensin system were measured concurrently in one blood sample; the concentrations of renin, angiotensin I, and angiotensin II were low, while renin-substrate was normal (table II). 
TABLE II-Concurremt Measurements of the Circulating Concentrations of Renin, Renin-substrate, Angiotensin I, Angiotensin II, and Aldosterone (Figures in Parentnsese are Normal Ranges)

\begin{tabular}{|c|c|c|c|c|c|c|}
\hline \multirow{2}{*}{$\begin{array}{l}\text { Na Intake } \\
\text { (mEq/day) }\end{array}$} & \multicolumn{6}{|c|}{ Plasma } \\
\hline & $\underset{(U \text { (Units/1.) }}{\text { Renin }}$ & $\begin{array}{c}\text { Renin-substrate } \\
(\mu \text { mol. }) \\
(0 \cdot 45-1 \cdot 28)\end{array}$ & $\begin{array}{l}\text { Angiotensin I } \\
\text { (pg/ml) } \\
(11-88)\end{array}$ & $\begin{array}{c}\text { Angiotensin II } \\
\text { (pg/ml) } \\
(5-35)\end{array}$ & $\underset{(\mathrm{mEq} / \mathrm{l} .)}{\mathrm{Na}}$ & $\underset{(\mathbf{m E q} / \mathbf{l} .)}{\mathbf{K}}$ \\
\hline 104 & $4 \cdot 1$ & 0.95 & 6 & 4 & 141 & 4.5 \\
\hline
\end{tabular}

BFFECT OF ANGIOTENSIN INFUSION ON PLASMA ALDOSTERONE CONCENTRATION

As shown in fig. 2, during intravenous infusion of angiotensin plasma aldosterone concentration increased from undetectable levels to the middle of the normal range. It is noteworthy that during these studies the changes in the plasma concentrations of aldosterone and angiotensin II were roughly parallel (fig. 2).

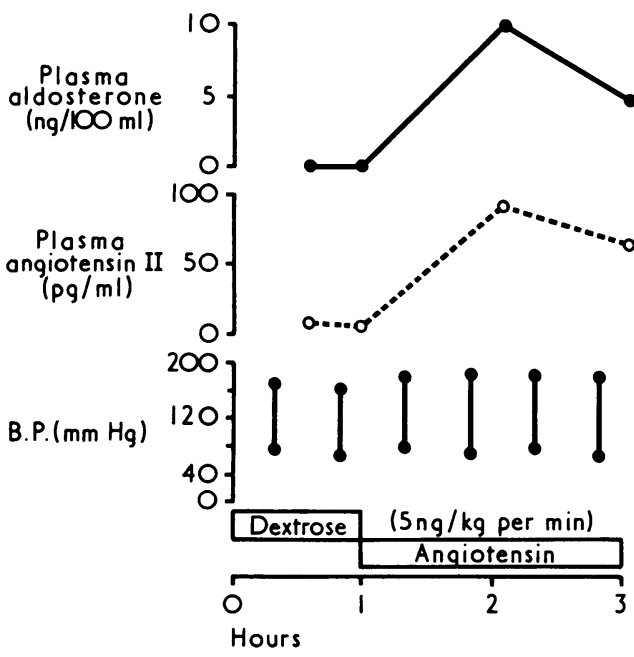

PIG. 2-Effect of angiotensin infusion on the plasm concentrations of aldosterone and angiotensin $\mathrm{II}$, and on blood pressure.

\section{KIDNEY RENIN CONTENT}

The extractable renin in the kidney was low at 1.2 units/g. tissue (three other kidneys obtained at necropsy and processed at the same time contained between $2 \cdot 2$ and 124 units/g tissue).

\section{TRRATMENT WITH FLUDROCORTISOI}

As shown in fig. 3, treatment with fludrocortisol corrected the electrolyte abnormalities, there being a progressive fall in the serum concentrations of $\mathrm{K}$ ( 6.0 to $3.7 \mathrm{mEq} / 1$.), chloride (112 to $102 \mathrm{mEq} / 1$.), and urea $(72$ to $48 \mathrm{mg} / 100 \mathrm{ml}$ ) accompanied by a rise in the serum concentration of $\mathrm{HCO}_{2}$ (15 to $26 \mathrm{mmol} / \mathrm{l}$.). During the first three weeks body weight increased by $4 \mathrm{~kg}$ and thereafter remained steady; oedema did not develop and blood pressure remained unchanged around $190 / 90 \mathrm{~mm} \mathrm{Hg}$.

\section{FURTHER PROGRESS}

Treatment with fludrocortisol was maintained $(0.1 \mathrm{mg} /$ day $)$ and the patient remained well until the sudden onset of anterior chest pain with breathlessness some six weeks later. On readmission to hospital, the diagnosis of myocardial ischaemia was confirmed by the appearance of $S-T$ and $T$ waye changes on the electrocardiogram; the serum concentration of cardiac enzymes remained normal (S.G.O.T. 15, S.G.P.T. 10 units $/ \mathrm{ml}$; lactic acid dehydrogenase $145 \mathrm{mU} / \mathrm{ml}$ ). She made an uneventful recovery and then remained well for a further four months before the sudden onset of a left-sided hemiplegia

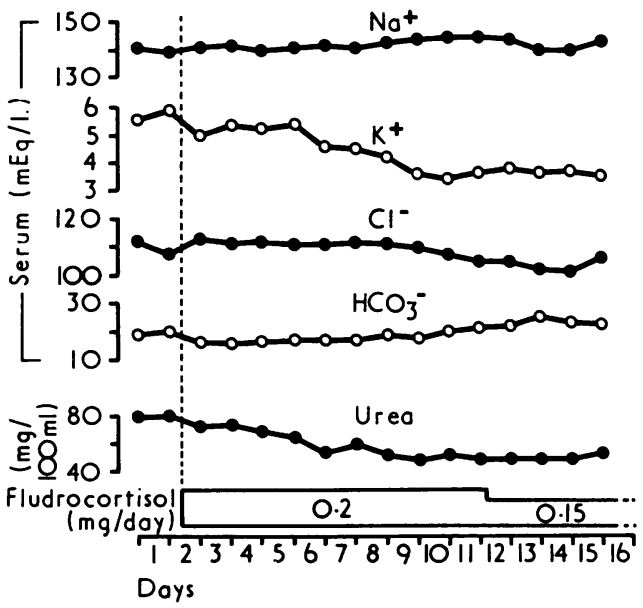

FIG. 3-Effect of treatment with fludrocortisol on serum electrolytes and urea.

caused admission to another hospital. On admission the blood pressure was $170 / 70 \mathrm{~mm} \mathrm{Hg}$ and the serum electrolytes were normal ( $\mathrm{Na} 138$, $\mathrm{K} 4 \cdot 3, \mathrm{Cl} 106, \mathrm{HCO}_{3} 23 \mathrm{mEq} / 1$ ); blood urea also normal (32 mg/ $100 \mathrm{ml}$ ). Bilateral bronchopneumonia developed and she died a few days later.

\section{NECROPSY}

The postmortem examination ( 20 hours after death) showed cerebral infarction and bilateral bronchopneumonia.

Adrenal Glands (Dr. Munro-Neville).-The left adrenal gland weighed $5.9 \mathrm{~g}$ and the right $7.0 \mathrm{~g}$. On the cut surface several small nodules were seen. Histological examination showed a cortex of "normal or slightly less than normal width with numerous micronodules in the periphery. The zona glomerulosa was not prominent but was present focally." The appearances of the pituitary gland were within normal limits.

Kidneys (Dr. R. F. Macadam)-_"Marked atheroma in one main renal artery; both kidneys show random changes of ischaemic nephrosclerosis." Sections stained by the periodic-acid Schiff and Bowie techniques showed a "numerically normal population of juxtaglomerular epitheloid cells. Secretion granules were not demonstrated."

\section{Discussion}

SYNDROME OF ISOLATED HYPOALDOSTERONISM

The clinical features of acquired selective deficiency of aldosterone are well recognized; they include weight loss and malaise with recurring episodes of muscular weakness, mental confusion, and heart block occurring particularly in elderly patients. Support for the diagnosis is most easily obtained by estimating plasma (or serum) electrolytes since hyperkalaemic acidosis without a grossly raised blood urea is usual. Final confirmation depends on the finding of low aldosterone values which fail to rise in the normal way during sodium deprivation, despite cortisol levels which rise normally both in the early part of the day and in response to injected ACTH.

That the symptomatology is caused by the electrolyte derangements has been shown by the prompt clinical improve- 
ment when these are corrected and by the rapid return of symptoms when similar electrolyte disturbances are induced acutely (Hudson et al., 1957). That the disordered electrolyte pattern is due primarily to the deficiency of aldosterone is shown by the beneficial response to treatment with this corticosteroid (Hokfelt and Skanse, 1960; Jacobs and Posner, 1964) or other sodium retaining corticosteroids. It is noteworthy, however, that only a minority of Addisonian patients with cortisone as the sole replacement therapy develop this syndrome (Hills et al., 1956; Morse et al., 1959; Hills, 1959). This suggests that the renal effects of angiotensin may be important in maintaining homeostasis since angiotensin is not deficient in Addison's disease Brown et al., 1972).

\section{CAUSES OF ISOLATED ALDOSTERONE DEFICIENCY}

Several cases of selective hypoaldosteronism in infancy have been ascribed to congenital enzyme deficiencies leading to defects in the later stages of aldosterone biosynthesis (Visser and Cost, 1964; Ulick et al., 1964). A similar mechanism was possibly involved in several adult cases (Wilson and Goetz, 1964; Vagnucci, 1969; Jacobs and Posner, 1964); one of these (Wilson and Goetz, 1964) had received prolonged treatment with heparin - a substance which is said to interfere with aldosterone synthesis (Cejka et al., 1960; Glaz and Sugar, 1964; Conn et al., 1966; Sharma et al., 1967; Bailey and Ford, 1969). The normal levels of cortisol and corticosterone (measured by specific isotope techniques) taken with the brisk increase in plasma "cortisol" after stimulation with ACTH affords no evidence for a biosynthetic block in the patient reported here although the plasma deoxycorticosterone concentration was marginally high.

The alternative possibility that selective hypoaldosteronism may be due to "a primary angiotensin inadequacy," thus implying low circulating levels of angiotensin II in this syndrome, was first put forward by Jacobs and Posner (1964). This suggestion has been supported directly by Perez et al. (1972) and in the studies reported here; the failure of angiotensin II to rise normally during sodium depletion being particularly noteworthy. That the low plasma angiotensin II was not due to identifiable defects within the renin-angiotensin system itself is shown by the normal renin-substrate level associated with concurrently low circulating concentrations of renin, angiotensin I, and angiotensin II (table 2). The plasma concentration of renin-substrate was normal also in the patients studied by Schambelan et al. (1972) and Weidman et al. (1972); low plasma renin activity in this syndrome has been reported by several groups (Vagnucci, 1969; McGiff et al., 1970; Vagnucci, 1970; Ferrara et al., 1970, Stockigt et al., 1971; Perez et al., 1972; Schambelan et al., 1972; Weidman et al., 1972).

The distinct rise in plasma aldosterone concentration, along with the roughly parallel changes in circulating angiotensin II during angiotensin infusion (fig. 2) is further evidence in favour of the idea that acquired hypoaldosteronism, at least in some cases, is secondary to angiotensin deficiency.

Previous studies investigating the effect of infused angiotensin on aldosterone values in this syndrome have provided varying results, perhaps due in part to the differing techniques used. In most studies aldosterone or a conjugate was measured in urine collected over a 24-hour interval which included a two to eight-hour angiotensin infusion. Urinary aldosterone remained unchanged in these patients (Wilson and Goetz, 1964; Vagnucci, 1969, 1970; Perez et al., 1972; Schambelan et al., 1972), but it was distinctly raised in another study in which angiotensin was apparently infused for 24 hours (Küchel et al., 1965). Aldosterone secretion has been estimated across angiotensin infusion in two other cases, a three-fold increase being recorded in one (McGiff et al., 1970) and no change in the other (Gerstein et al., 1968). Plasma aldosterone was estimated in the remaining study, reported only in abstract form, and a "definite" increase was noted (Weidman et al., 1972). The changes in plasma aldosterone observed in our patient (at least five-fold) are probably too large to be accounted for other than by a genuine increase in the rate of secretion. It is noteworthy that the circulating angiotensin levels during the infusion were not far in excess of those noted in this laboratory when aldosterone was stimulated by experimental sodium deprivation (Brown et al., 1972d).

\section{CAUSE OF THE LOW PLASMA RENIN CONCENTRATION}

The low extractable renal renin, taken with the absence of juxtaglomerular granules, favours the possibility that the low plasma renin values might have been caused by reduced production or storage of the enzyme rather than to suppression of the releasing mechanisms.

Leaving aside the mechanism of the low renin values, the present studies strongly support the idea that, in some patients at least, selective hypoaldosteronism is due to the low circulating levels of angiotensin II. This suggestion has wide implications concerning the control of aldosterone secretion by angiotensin, a topic which remains controversial (Bledsoe et al., 1966; Best et al., 1971; Blair-West et al., 1972; Boyd et al., 1972; Brown et al., 1972d). The failure of both sodium depletion and hyperkalaemia to stimulate aldosterone in our patient, taken together with the prompt, roughly parallel rise in the plasma concentrations of both angiotensin and aldosterone when angiotensin was infused, suggests a central role for the reninangiotensin system in the control of aldosterone.

From the clinical point of view it is important to suspect the possibility of selective hypoaldosteronism in all cases of unexplained hyperkalaemia since replacement therapy with fludrocortisol is such a simple and effective therapy.

We are grateful to the patient and her family for their interest and eager co-operation. We are also grateful to Drs. J. G. Sclater and A. P. Littlewood for access to the earlier clinical records and to Dr. A. R. Mandal for providing data concerning the final illness.

\section{References}

Bailey, R. E., and Ford, H. C. (1969). Acta Endocrinologica (Kobenhavn), 60,249 .

Beardwell, C. G., Burke, C. W., and Cope, C. L. (1968). fournal of Endocrinology, 42,79.

Best, J. B., Bett, J. H. N., Coghlan, J. P., Cran, E. J., and Scoggins, B. A. (1971). Lancet, 2, 1353

Blair-West, J. R. et al. (1972). Proceedings of the IVth International Congress of Nephrology (Stockholm, 1969), vol. 2, p. 33. Basel, Karger.

Bledsoe, T., Island, D. P., and Liddle, G. W. (1966). Fournal of Clinical

Investigation, 45, 524.
Boyd, G. W., Adamson, A. R., Arnold, M., James, V. H. T., and Peart, Woyd, G. W. (1972). Clinical Science, 42, 91 .

Wrown, J. J. et al. (1972a). Clinical Science, 42, 28p.

Brown, J. J. et al. (1972a). Clinical Science, 42, 28p. in Endocrinology and Metabolism, 1, 397

Brown, J. J. et al. (1972c). Lancet, 1, 243.

Brown, J. J. et al. (1972d). Lancet, 2, 1106.

Cejka, V., et al. (1960). Lancet, 1, 317.

Chinn, R. H., and Düsterdieck, G. (1971). Clinical Science, 42, 489.

Conn, J. W., Rovner, D. R., Cohen, E. L., and Anderson, J. E. (1966). Fournal of Clinical Endocrinology and Metabolism, 26, 527 .

Counihan, T. B., Evans, B. M., and Milne, M. D. (1954). Clinical Science, 13,583 .

Ferrara, E., Werk, E., Hanenson, I., Privitera, P., and Kenyon, C. (1970). Clinical Research, 18, 602.

Gerstein, A. R., et al. (1968). Nephron, 5, 90.

Glaz, E., and Sugar, K. (1964). Endocrinology, 74, 159

Hill, S. R., et al. (1959). Archives of Internal Medicine, 104, 982

Hills, A. G. (1959). American fournal of Medicine, 26, 503 .

Hills, A. G., Zintel, H. A., and Parsons, D. W. (1956). American fournal of Medicine, 21, 358.

Hokfelt, B., and Skanse, B. (1960). Acta Endocrinologica (Kpbenhavn), 33, 511 .

Hudson, J. B., Chobanian, A. V., and Relman, A. S. (1957). New England fournal of Medicine, 257, 529.

Jacobs, D. R., and Posner, J. B. (1964). Metabolism, 13, 522.

Johnson, R. H., McLellan, D. L., and Love, D. R. (1971). Fournal of Neurology, Neurosurgery and Psychiatry, 34, 562. 
Küchel, O., Horky, K., Gregorova, I., and Petrasek, J. (1965). Klinische Wochenschrift, 43, 1318

Lambrew, C. T., Carver, S. T., Peterson, R. E., and Horwith, M. (1961) American fournal of Medicine, 31,81 .

McGiff, J. C., et al. (1970). American fournal of Medicine. 48, 247.

Mellinger, R. C., Petermann, F. L., and Jurgenson, J. C. (1972). fournal of Clinical Endocrinology, 34, 85

Morse, W. J., et al. (1959). American fournal of Medicine, 26, 315

Murphy, B. E. P. (1967). Fournal of Clinical Endocrinology and Metabolism, $27,973$.

Perez, G., Siegel, L., and Schreiner, G. E. (1971). Clinical Research, 19, 543. Perez, G., Siegel, L., and Schreiner, G. E. (1972). Annals of Internal Medicine, 76, 757 .

Posner, J. B., and Jacobs, D. R. (1964). Metabolism, 13, 513.

Rick, W., Winkler, G., Koch, E., and Bohn, H. (1962). Acta Endocrinologica (Kobenhavn), Suppl. No. 67, p. 103.

Schambelan, M., Stockigt, J. R., Collins, R. D., and Biglieri, E. G. (1972). Clinical Research, 20, 220.

Sharma, D. C., Nerenberg, C. A., and Dorfman, R. I. (1967). Biochemistry, 6, 3472 .
Skanse, B., and Hokfelt, B. (1958). Acta Endocrinologica (Kфbenhavn), 28, 29.

Stockigt, R. D., Collins, R. D., Schambelan, M., Brust, N., and Biglieri, E. G. (1971). Clinical Research, 19, 382

Tree, M. (1973). Fournal of Endocrinology, 56, 159.

Tree, M. (1972). Ph.D. Thesis. University of Glasgow.

Ulick, S., et al. (1964). Fournal of Clinical Endocrinology and Metabolism, 24, 669.

Vagnucci, A. H. (1969). Fournal of Clinical Endocrinology and Metabolism, 29, 279.

Vagnucci, A. H. (1970). Nephron, 7, 524.

Visser, H. K. A., and Cost, W. S. (1964). Acta Endocrinologica (Kфbenhavn), $47,589$.

Waite, M. A. (1972a). Fournal of Physiology, 222, 88P.

Waite, M. A. (1973b). Clinical Science. In press.

Weidman, P., et al. (1972). Clinical Research, 20, 249.

Wilson, I. D., and Goetz, F. C. (1964). American fournal of Medicine, 36, 635

Wrong, O., and Davies, H. E. F. (1959). Quarterly fournal of Medicine, 28, 259 .

MEDICAL MEMORANDA

\section{Intravascular Coagulation Complicating Influenza A Virus Infection}

\section{A. M. DAVISON, D. THOMSON, J. S. ROBSON}

\section{British Medical fournal, 1973, 1, 654-655}

Virus infections may produce intravascular coagulation (McKay and Margaretten, 1967). This paper reports two instances, both in young people, in whom infection with influenza $A$ virus resulted in intrarenal fibrin deposition sufficient to produce renal failure. An epidemic of a new strain of influenza (A/Eng/42/72) virus infection may be expected (British Medical fournal, 1972) and we wish to draw attention to this potentially fatal complication.

\section{Case 1}

A healthy girl of 14 developed nausea, anorexia, and giddiness 10 days after her sister had had similar symptoms. Two days later she noticed haematuria and she had a haemoptysis and haematemesis. She was treated with tetracycline and salicylates but two days later was noted to be slightly jaundiced, and was admitted to hospital.

On admission she was pale, slightly jaundiced, and drowsy. Physical examination showed nothing abnormal apart from widely scattered coarse crepitations. Urine analysis showed many red cells and protein. Biochemical and haematological findings are shown in the table. Bacteriological examination of blood, nose swabs, throat swabs, sputum, and midstream urine produced no abnormality.

The day after admission a renal biopsy was performed after a platelet transfusion. Light microscopy showed a diffuse increase in the number of endothelial and mesangial cells with an associated focal acute tubular necrosis. Immunofluorescence showed fibrin/fibrinogen in glomerular capillary walls which in some areas was sufficient to occlude the lumen. No immunoglobulin or complement was detected.

\footnotetext{
Department of Pathology, University of Edinburgh, Edinburgh
EH8 9AG

A. M. DAVISON, M.B., M.R.C.P., Research Fellow

D. THOMSON, M.B., M.R.C.PATH., Senior Lecture

Medical Renal Unit, Department of Medicine, The Royal Infirmary, Edinburgh EH3 9YW

J. S. ROBSON, M.D., F.R.C.P., Reader
}

Biochemical and Haematological Findings in the Two Cases Under Study

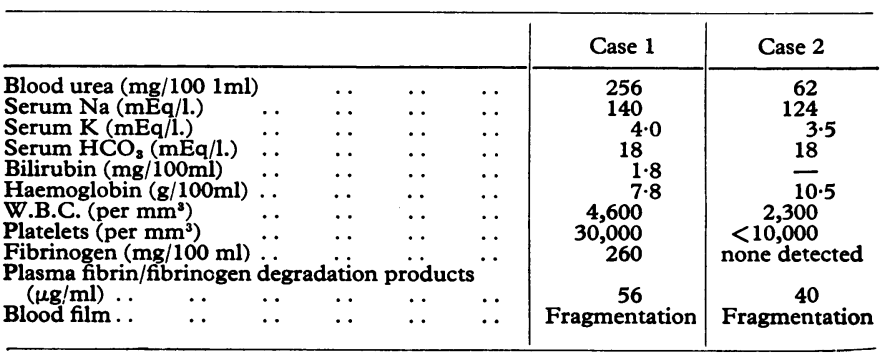

Her blood urea concentration rose to $310 \mathrm{mg} / 100 \mathrm{ml}$ over the next 48 hours and was associated with oliguria. Haemodialysis with a Kolff artificial kidney and an Ultraflo 100 coil under regional heparinization was performed on five occasions, after which there was a satisfactory return to normal renal function. No therapy and in particular no antibiotics or anticoagulants were given.

The abnormal haematological indices returned to normal. Complement fixing antibody titre to influenza $A$ virus rose from $1 / 16$ to $1 / 256$ three weeks later. A repeat biopsy showed resolution of the renal lesions and immunofluorescence showed the presence of small amounts of fibrin/fibrinogen within a few glomerular capillary walls.

Twenty-five days after admission the patient was discharged and remained well.

\section{Case 2}

The second patient, a 14-year-old boy, developed an upper respiratory tract infection and vague muscular pains. He was treated with ampicillin but four days later his symptoms had not improved, he became pyrexial and dyspnoeic, and was admitted to hospital. After admission his dyspnoea became more severe, he became cyanosed, and died from a massive haemoptysis before artificial ventilation could be instituted. Biochemical and haematological investigations are shown in the table. Tracheal secretions produced a scanty growth of Staphylococcus aureus; blood culture was negative.

At necropsy fluid blood was found in the nasal, oral, and respiratory passages and both lungs showed intense haemorrhagic congestion. Petechial haemorrhages were present in the cerebral white matter but other organs showed only congestion.

Influenza $\mathrm{A}$ virus was identified by culture from tracheal and lung tissue. Lung histology showed widespread haemorrhagic destruction of parenchyma and ulceration of the respiratory mucosa. Renal histology showed granular material suggestive of fibrin within glomerular capillaries. There was a slight increase in mesangial cells, and denuded endothelial cell nuclei characteristic of intravascular coagulation (Brown et al., 1969) were seen lying free 